\title{
AN IMPLEMENTATION OF E-LEARNING BASED MOODLE TO DEVELOP MATHEMATICAL COMMUNICATION SKILL AND SELF- EFFICACY
}

\author{
Linda Astriani $^{1}$, Dewi Setiyaningsih ${ }^{2}$, Misriandi $^{3}$, Anggie Yuliani ${ }^{4}$ \\ ${ }^{1}$ Universitas Muhammadiyah Jakarta, Jln. KH Ahmad Dahlan, Tangsel, Indonesia \\ lindaastriani@umj.ac.id \\ ${ }^{2}$ Universitas Muhammadiyah Jakarta, Jln. KH Ahmad Dahlan, Tangsel, Indonesia \\ dewi.setiyaningsih@umj.ac.id \\ ${ }^{3}$ Universitas Muhammadiyah Jakarta, Jln. KH Ahmad Dahlan, Tangsel, Indonesia \\ misriandi@yahoo.co.id \\ ${ }^{4}$ Universitas Muhammadiyah Jakarta, Jln. KH Ahmad Dahlan, Tangsel, Indonesia \\ anggieyulianti29@gmail.com
}

\begin{abstract}
Mathematical communication skills are important, and education should facilitate students to improve their mathematical communication skills. The purpose of this study was to develop e-learning based on Moodle to improve students' mathematical communication and self-efficacy and student self-efficacy and describe how to students' mathematic communication and student self-efficacy. This study used mixed-method research. The population in this study were Year 5 students at a private primary school. Data collection techniques used in this study are observation and tests. The implementation with Moodle was effective to the students' mathematic communication and self-efficacy student. Overall, the students' mathematical communication skills and selfefficacy of students using E-learning based Moodle is better than those using conventional learning. Also, selfefficacy positively affects students' communication skills with a very strong correlation coefficient, meaning that the higher students' self-efficacy, the higher students' communication skills.
\end{abstract}

\section{ARTICLE INFORMATION}

\begin{tabular}{lll}
\hline Keywords & & Article History \\
\hline E-learning & & Submitted Sep 30, 2021 \\
Moodle & & Revised Nov 6, 2021 \\
Mathematics Communication & & Accepted Nov 11, 2021 \\
Self-Efficacy & & \\
\cline { 1 - 2 } Corresponding Author & \\
\hline
\end{tabular}

Linda Astriani

Universitas Muhammadiyah Jakarta

Jln. KH Ahmad Dahlan, Ciputat Tangsel, Indonesia

Email: lindaastriani@umj.ac.id

\section{How to Cite}

Astriani, L., Setiyaningsih, D., Misriandi., M., \& Yuliani, A. (2021). An Implementation of E-Learning Based Moodle to Develop Students' Mathematical Communication Skills and Self-Efficacy. Kalamatika: Jurnal Pendidikan Matematika, 6(2), 207-218. 
208 KALAMATIKA, Volume 6, No. 2, November 2021, pages 207-218

https://doi.org/10.22236/KALAMATIKA.vol6no2.2021pp207-218 


\section{INTRODUCTION}

The development of science and technology continues to develop. Moodle can improve student achievement, motivation, communication, interest, discipline and increase selfconfidence. Preparing smart, wise, and critical young people with the ability to complete assignments and communicate or convey the information to others can be done through elearning based on Moodle, mathematics learning trains students to think systematically and structured.

The E-Learning model utilizes the development of information and communication technology. E-learning activities in the learning model aim to make it easier for students to explore knowledge as widely as possible, both in groups and individually. The National Education Association (n.d.) has identified 21st-century skills as "The 4Cs." "The 4Cs" include critical thinking, creativity, communication, and collaboration (Chiruguru, 2020). Critical thinking skills are skills to carry out various analyses, assessments, evaluations, reconstructions, decision-making that lead to rational and logical actions (F.J et al., 2010). Based on this information, communication skills or communication skills are important in improving competence. Therefore, a strategy is needed to help improve the quality of learning to produce competent students following 21 st-century skills.

Based on research from Nur \& Waluya (2015), some students in the team may have difficulty and cannot even understand the material even though they have discussed and received help from other groups. For this reason, an appropriate learning model is needed that can improve students' mathematical communication skills and self-efficacy. Meanwhile, according to Sokoine (2015), the course respondents were important for acquiring the communication skills needed in their academic life. So, students need to have mathematical communication skills. To improve interaction and expression of ideas in the classroom can be using communication in mathematics because students learn in an active atmosphere. There are many applications or learning models to improve student study in the classroom. One of them is Moodle, e-learning based Moodle is one of the learning models recommended by the 2013 curriculum development team to improve learning with the help of technology and information.

Moodle is an application program to convert learning media into a web form. Elearning based on Moodle products allows students to enter digital classrooms to access course 
materials. The advantages of Moodle include creating learning materials, quizzes, discussion forums, or online chats, inserting an image or video media, and having a database that can store data and student attendance online, all in an e-learning unit. This study aims to develop e-learning based on Moodle to improve students' mathematical communication and selfefficacy.

The following will describe some of the literature published in the previous journals. First: "Mathematical Communication Ability Judging from the Character of Collaboration in Project-Based Learning (PJBL)" written by (Ning et al., 2017), in this study the characteristics of mathematical communication skills that students high ability to have mathematical language representation skills, verbal problem solving, mathematical thinking, mathematical decisions, mathematical considerations, reasoning against other people's ideas get a very good category. The moderately capable students have mathematical language representation skills, verbal problem solving, mathematical thinking, reasons for other people's ideas get very good categories, mathematical decisions, mathematical considerations get good categories. Lowability students have mathematical language representation abilities, verbal problem solving gets a very good score, while for reasons against other people's ideas, mathematical considerations get good categories and on mathematical thinking, and mathematical decisions are sufficient. The second "Implementation of E-learning to Develop student self-efficacy" research was written by (Wahyudin et al., 2019). This study concluded that: 1) The Self Efficacy of students who get the e-learning learning model is not better or relatively the same as Self Efficacy of students who get conventional learning, 2) Factors that can improve students' mathematical reasoning abilities and self-efficacy with e-learning according to students' opinions are students' self-motivation, pleasant learning atmosphere, adequate facilities and pleasant teacher attitudes (Wahyudin et al., 2019). Based on previous research, the researchers aimed to develop a learning model that can facilitate the learning activity process to optimize the student's mathematical communication and self-efficacy capabilities by E-learning Moodle.

\section{METHOD}

This study used a mixed method. Data collection was done using concurrent embedded strategy, namely a research strategy that combines the use of quantitative and qualitative research together, but the weight of the method is different (Creswell, 2014). In 
this study, quantitative research was the primary method, while qualitative research was a secondary method. The qualitative research supported the data to analyze students' selfefficacy students. This research began with the collection and quantitative data analysis and ended with the collecting of qualitative data.

The design of this study uses experimental and control classes. This study requires experimental and control class and only does a post-test. The treatment is only given to the experiment class, namely using project-based learning with E-learning based in Moodle. The research design is:

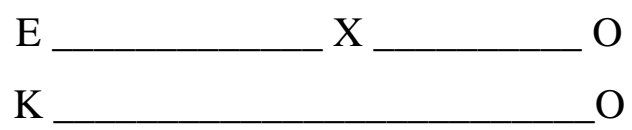

Note:

$$
\begin{aligned}
& \mathrm{E}=\text { Experiment } \\
& \mathrm{K}=\text { Control } \\
& \mathrm{X}=\text { Treatment } \\
& \mathrm{O}=\text { Post Test }
\end{aligned}
$$

This research consisted of two steps: the pre-field and the fieldwork. At the pre-field step, the researcher developed the research design, selected the research place, applied for ethics, conducted initial observations, developed research equipment including lesson plans, teaching materials, tests of mathematic communication, and a self-efficacy survey. The compiled equipment is validated first by an expert validator. The fieldwork started by selecting a sample consisting of one experimental class and one control class based on random sampling technique, namely the experimental class using e-learning based Moodle, while the control class using conventional learning. This research used SPSS to analyze the data.

\section{RESULT AND DISCUSSION}

\section{Student's Self-Efficacy}

\begin{tabular}{|c|c|c|c|c|}
\hline Dimension & Indicator & Statement & Score & Average \\
\hline \multirow[t]{2}{*}{ Magnitude } & $\begin{array}{l}\text { 1.a Student confidence to be able to try harder in achieving } \\
\text { success in learning mathematics }\end{array}$ & $1-9$ & 531 & 59 \\
\hline & $\begin{array}{l}\text { 1.b Students' confidence to be able to carry difficult tasks in } \\
\text { learning mathematics }\end{array}$ & $10-15$ & 382 & 64 \\
\hline Strength & 2.a Being able to deal with obstacles that occur in learning & $16-21$ & 396 & 66 \\
\hline
\end{tabular}

The recapitulation of students' self-efficacy achievements in learning mathematics and the recapitulation of self-efficacy data can be presented in Table 1.

Table 1. The results of the recapitulation of self-efficacy 


\begin{tabular}{|c|c|c|c|c|}
\hline & $\begin{array}{l}\text { Mathematics well } \\
\text { 2.b Being able to work hard, diligently and ready to adapt in } \\
\text { any given Math task }\end{array}$ & $22-28$ & 765 & 59 \\
\hline \multirow{2}{*}{ Generality } & 3.a Can achieve good results for what has been done & $29-34$ & 353 & 59 \\
\hline & 3.b Can accept new things in learning Mathematics well. & $35-40$ & 351 & 59 \\
\hline
\end{tabular}

They are 40 questions self-efficacy instrument with six self-efficacy indicators. Based on the table, the average indicator of students having confidence in learning mathematics is $59 \%$, and the indicator of student confidence in carrying out difficult tasks in learning mathematics is $64 \%$. This means that students are quite sure that they can complete the task of learning mathematics. The third indicator gets the highest average of $66 \%$; this shows that students can face obstacles when participating in mathematics learning. As for the indicator of working hard, diligently, and ready to adapt to any given math task, the average score is 59\%. In addition, the indicators for achieving good results and accepting new things in learning mathematics both get an average of 59\%. From these results, it can be said that students are good enough for themselves, especially in mathematic communication learning. According to Bandura in Jess Feist and Gregory J. Feist (Feist \& Gregory, 2013) argues that Self Efficacy is a person's belief in his ability to exercise some form of control over the person's functioning and events in the environment.

\section{Mathematic Communication}

Based on the results, it was found that overall, the achievement of mathematical communication skills students using e-learning based on Moodle was better than those using conventional learning. The category of students' achievement of mathematical communication skills using e-learning based on Moodle, while students who use conventional learning are moderate. The effect size of e-learning based on Moodle on the achievement of mathematical communication indicators is presented in Table 2.

Table 2. Dimension and Indicators Mathematical Communications

\begin{tabular}{lll}
\hline \multicolumn{1}{c}{ Dimension } & \multicolumn{1}{c}{ Indicator } \\
\hline a. Writing Skills (Written Texts) & $\begin{array}{l}\text { Explain the idea or solution of a problem or image by using their } \\
\text { language }\end{array}$ \\
b. Mathematic Expression Ability (Mathematical & $\begin{array}{l}\text { Express everyday problems or events in mathematical symbols. } \\
\text { Explain })\end{array}$ & $\begin{array}{l}\text { Explain ideas or solutions to mathematical problems in the form } \\
\text { of pictures. }\end{array}$ \\
\hline
\end{tabular}

Source: (NCTM, 2000)

The average score of the mathematical communication ability in the experimental class and the control class is presented in Table 3. Table 3 shows the Independent Sample Test that there is a difference of the mathematical communication skills between the experiment and 
control class $(\mathrm{p}=0.031)$. So, there is a significant difference in the results of students' mathematical communication abilities given the e-learning based Moodle and students who were not given the e-learning based Moodle.

Table 3. T-Test Results of Ability Differences in Experiment Class and Class Control of Mathematical Communication Skills

\begin{tabular}{lccccc}
\hline & \multicolumn{3}{c}{$\begin{array}{c}\text { Levene's Test for Equality of } \\
\text { Variances }\end{array}$} & \multicolumn{2}{c}{ t-test for Equality of Means } \\
\hline & $\mathrm{F}$ & Sig. & $\mathrm{t}$ & $\mathrm{df}$ & (2-tailed) \\
\cline { 2 - 6 } & .032 & .859 & 2.205 & 58 & 0.31 \\
Equal variances assumed & & & 2.205 & 57.922 & 0.31 \\
\hline
\end{tabular}

\section{E-learning based on Moodle}

Moodle is a name for a complete application program that can turn a learning media into a web form. As explained by (Jati, 2013) that Moodle is a sophisticated tool for creating and managing courses, checking student attendance and performance, managing quizzes and assignments, and surveys. There are several strong reasons, making Moodle one of the popular Learning Management Systems (LMS) used by many educational institutions, according to Deni Darmawan (2014), there are four strong reasons, including the first reason is free and open-source, the second is based on educational philosophy, Moodle is built based on direct experience in the field with a background in educational science. So that Moodle can accommodate almost all conventional educational needs transferred in the form of online learning. The third reason is a large and sharing community. The Moodle user community is part of an organization www.moodle.org. The fourth reason is, small size, maximum capability. With small size (only about $17 \mathrm{MB}$ for the Moodle 3.1) version, it can manage academic and learning activities up to the size of a university.

The implication of this principle in e-learning is to present together with the positions of relevant text and graphics so that users easily understand them; (1) Modality Principle, (2) Redundancy Principle, and (3) Coherence principle. So, the implementation of e-learning based Moodle in this research explains that if learning using the animation and present videos in e-learning, narration can be improved learning activities because multimedia messages from videos are spoken text so that they will be easier to understand (Mayer, R, 2009). Figure 2 show the first menu in Moodle. 


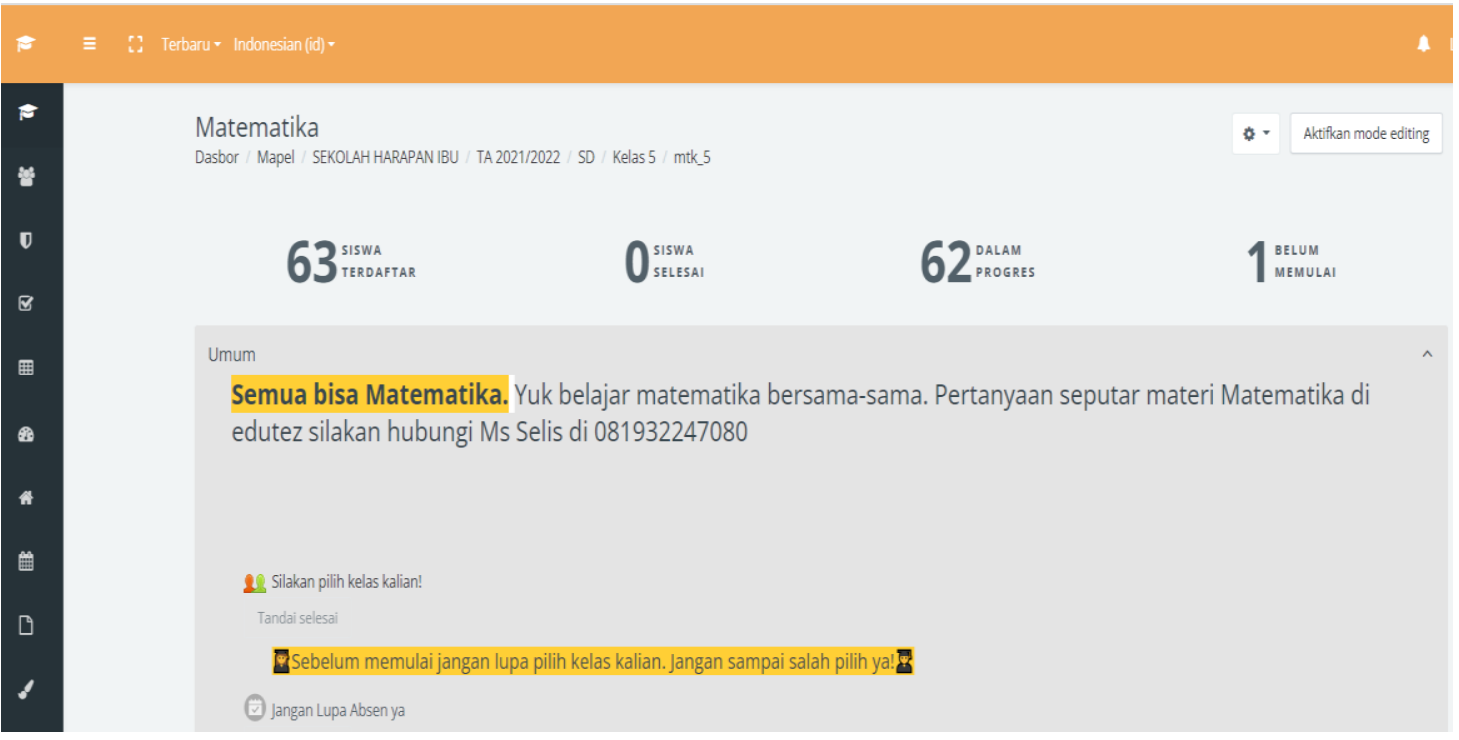

Figure 2. Mathematic subject menu in grade 5

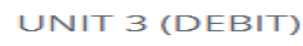

(․ㅡ SATUAN WAKTU

Lihat

\section{SATUAN WAKTU}

E.르. Latihan 10

Lihat Memperoleh nîlai Dapatkan nilaî kelulusan

(i) SATUAN VOLUME

Tandai selesai

SATUAN VOLUME

ت Mengubah Satuan Volume

\section{Lihat}

블 Latihan 11

Lihat Memperoleh nilai Dapatkan nilai kelulusan

DEBIT

Tandai selesai

\section{DEBIT}

표 Perhatikan video berikut!

\section{Lihat}

Figure 3. Subject material Debit 


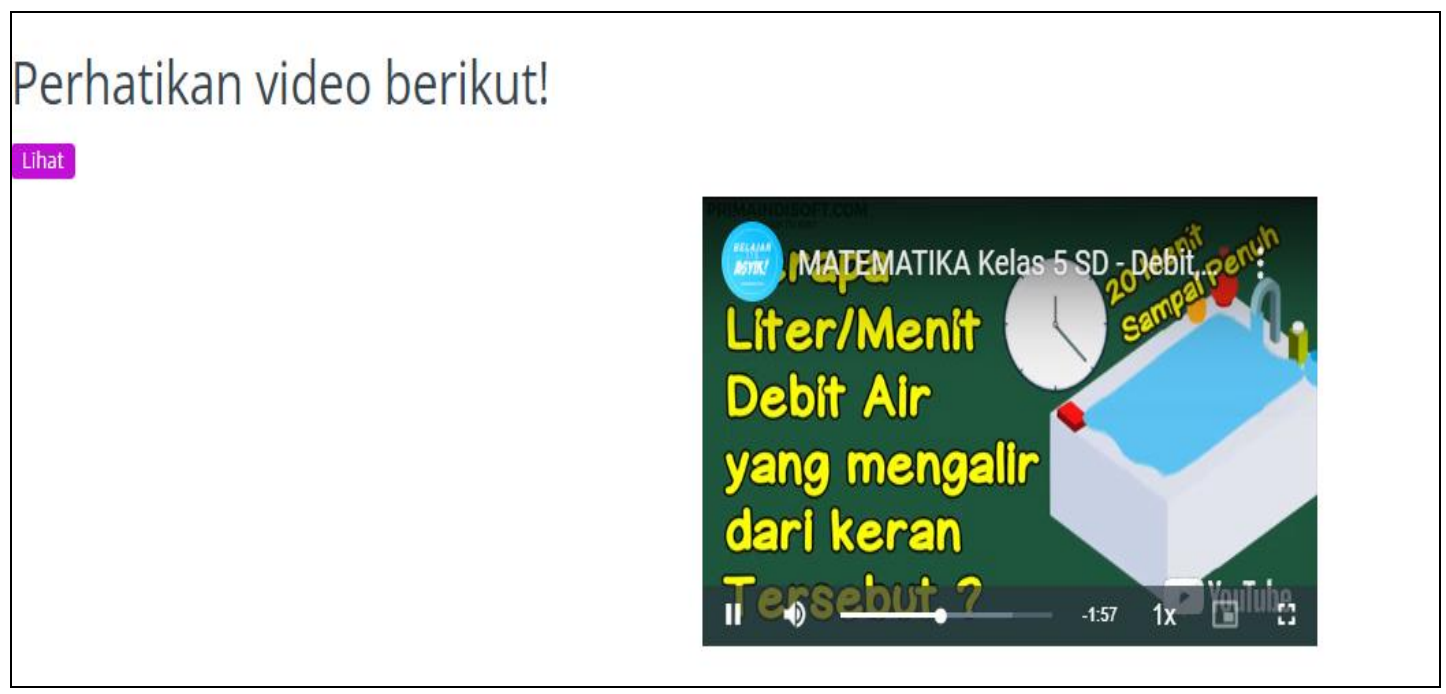

Figure 4. Video of material in debit

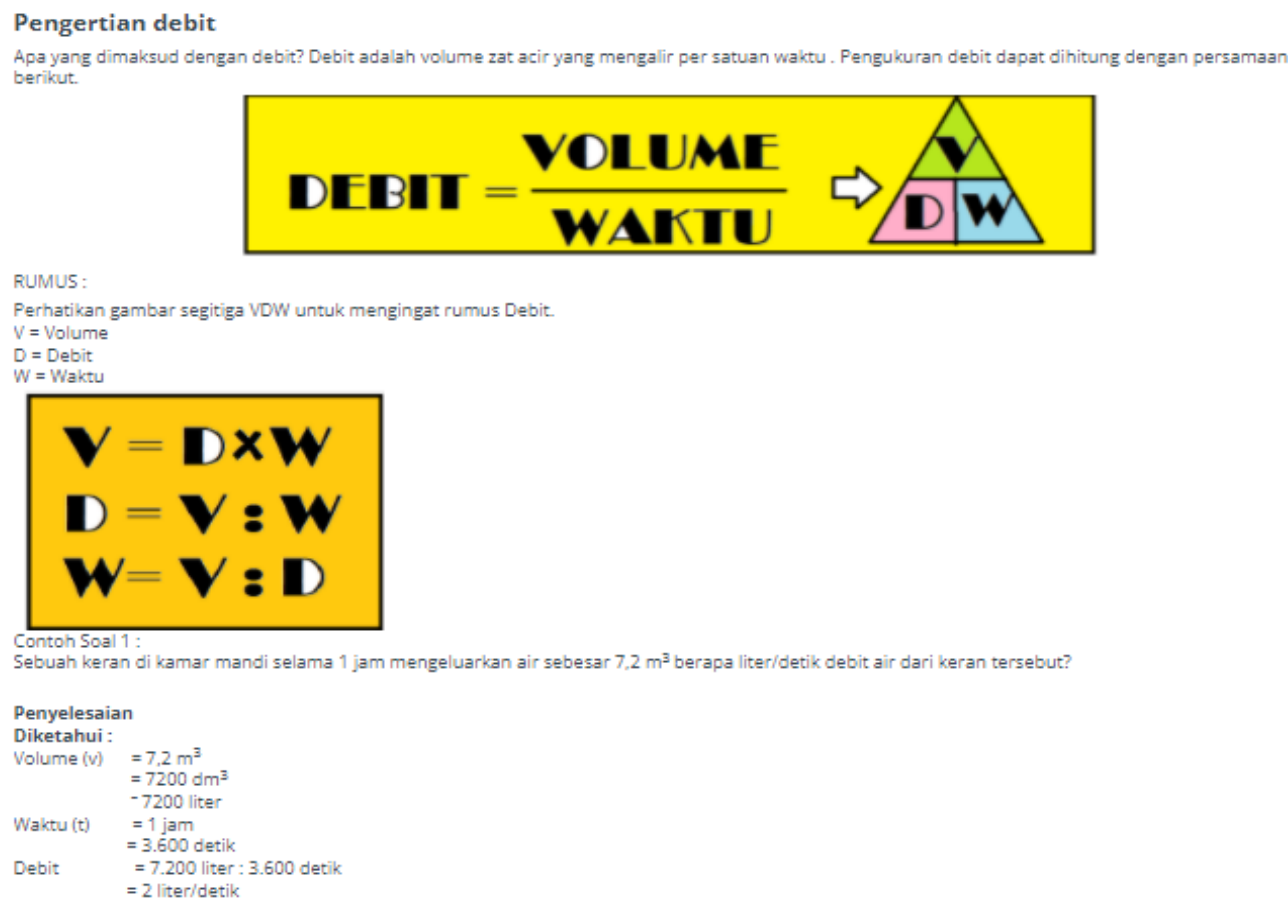

RUMUS:

Perhatikan gambar segitiga VDW untuk mengingat rumus Debit.

$V=$ Volume

$D=$ Debit

Sebuah keran di kamar mandi selama 1 jam mengeluarkan air sebesar $7,2 \mathrm{~m}^{3}$ berapa liter/detik debit air dari keran tersebut?

Penyelesaian

Diketahui :

$\begin{aligned} \text { Volume }(\mathrm{v}) & =7,2 \mathrm{~m}^{3} \\ & =7200 \mathrm{dm}^{3}\end{aligned}$

$=7200 \mathrm{dm}$

-7200 liter

$\begin{aligned} \text { Waktu (t) } & =1 \mathrm{jam} \\ & =3.600 \text { detik }\end{aligned}$

Debit $\quad=7.200$ liter : 3.600 detik

$=2$ liter/detik

Figure 5. Text material of debit 


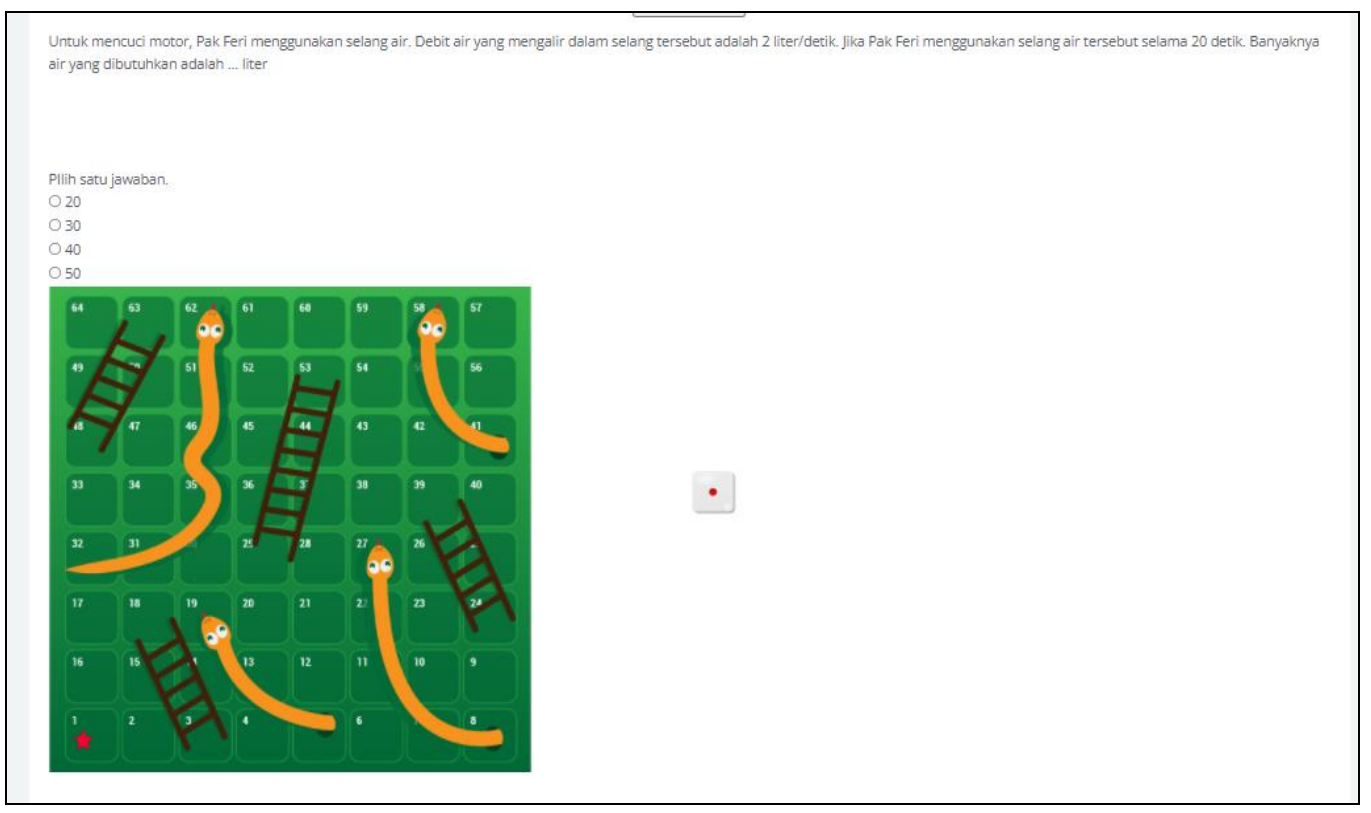

Figure 6. Snakes game for debit

Figure 2 shows the main menu of the Mathematic menu in Grade 5; students must be open the mathematics room. In this part, students can know their absent and teacher information. Figure 3 shows the Subject material of debit; in Unit 3 (Debit) before the students are studying debit, they have to understand other materials like time unit and volume unit. Figure 4: Students can see the video of the debit material; they can see the video on the schedule and after the class to better understand the materials 5: It was the text material of debit with the example. Figure 6: In Moodle, there is a games application menu. One of them is snake games; these games can make students feel happy when playing games, even though, in fact, they are working on questions made by their teacher in the form of snake games. We can see how the students using e-learning based on moodle improve their skills, not only in ICT but also in mathematical communication skills and self-efficacy.

\section{CONCLUSION}

Moodle provides complete features for a learning process, including features for communication (chat, messaging, or forums), features for the creation and administration of learning materials, features for tracking and following the development of the learning process (tracking data) with a user-friendly interface, easy to understand, flexible features for feature expansion (plugin extensibility) with support for API documentation facilities (guidelines, and templates for programming). Ease of use because almost all components in Moodle can be 
arranged externally and flexibly according to the policies and needs of the learning process in each institution. Available free of charge, as open-source software (under the GNU Public License), Moodle gives you the freedom to copy, use, and modify it. However, Moodle has some weaknesses too, such as a) it does not always support existing web browsers, although it can be updated by downloading the latest Moodle application, b) in the choice of language, some parts in the e-Learning display cannot be changed.

Based on the results and discussion, this research concludes that the implementation of e-learning based on Moodle in developing mathematical communication skills is better than students' abilities in conventional learning. There are differences in the students' achievement of mathematic communication and self-efficacy students between classes that use e-learning based on Moodle with conventional learning. As for the contribution (Effect Size) and selfefficacy has a positive effect on students' communication skills, meaning that the higher students' self-efficacy, the higher students' communication skills, then the value of the correlation coefficient are classified as very strong. Based on the results of this study, the authors recommend that the self-efficacy influences the level of students' mathematical communication skills, so to increase students' self-efficacy attitudes, it is also necessary to pay attention to learning that must be designed as well as possible.

The study results can be used as a reference to conduct further research on the use of certain learning strategies that can be used to measure the students' mathematical communication skills and self-efficacy. E-learning based on Moodle can be used as an alternative learning model for teachers to be applied in the classroom to improve students' mathematical communication skills and self-efficacy.

\section{ACKNOWLEDGMENTS}

This research can be carried out properly thanks to the assistance of various parties, for that the researchers would like to thank the Dean of Faculty of Education Muhammadiyah Jakarta University who has supported this research, Leader of P3M FIP UMJ, which has provided research grants for the odd semester of 2021/2022, and to the Headmaster of SD Islam Harapan Ibu, Pondok Pinang South Jakarta who has allowed researchers and the team to conduct the research at the school. 


\section{REFERENCES}

Chiruguru, D. S. B. (2020). National Education Association. (n.d.). Preparing 21st Century Students for a Global Society: An Educator's Guide to the "Four Cs. http://www.nea.org/assets/docs/AGuide-to-Four-Cs.pdf.

Creswell, J. W. 2014. (2014). Research Design: Pendekatan Kualitatif, Kuantitatif dan Mixed. Terjemahan Fawaid. Pustaka Pelajar.

Deni Darmawan. (2014). Pengembangan E-learning Teori dan Desain. Remaja Rosdakarya.

F.J, K., Goodson, L., M.S., \& Rohani, F. (2010). Higher Order Thinking Skills. Assessment dan Evaluation Educational Service Program.

Feist, J., \& Gregory. (2013). Teori Kepribadian (Theories of Personality). Salemba Humanika.

Jati, G. (2013). Learning Management System (Moodle) And E-Learning Content Development. Jurnal Sosioteknologi, 277-289. https://doi.org/10.5614/sostek.itbj.2013.12.28.3

Mayer, R, E. (2009). Multimedia learning (2nd ed.). Cambridge University Press.

NCTM. (2000). Principle and Standards for School Mathematics. VA: NCTM.

Ning, W., Kumalaretna, D., \& Harapan, S. M. K. T. (2017). Kemampuan Komunikasi Matematis Ditinjau dari Karakter Kolaborasi dalam Pembelajaran Project Based Learning (Pjbl). Unnes Journal of Mathematics Education Research, 6(2), 195-205.

Nur, N., \& Waluya, B. (2015). Analisis Komunikasi Matematis Dan Tanggung Jawab Pada Pembelajaran Formulate Share Listen Create Materi Segiempat. Unnes Journal of Mathematics Education Research, 4(2), 115-121.

Sokoine, S. C. K. (2015). The Perceived Importance of Communication Skills Courses among University Students: The Case of Two Universities in Tanzania. Journal International Journal of Education and Research, 497-508. 
Wahyudin, Y., Mubarika, M. P., \& Firmansyah, E. (2019). Implementasi E-learning untuk mengembangkan self efficacy siswa. Jurnal PJME, 9(1), 44-55. 